http://dx.doi.org/10.4314/jae.v16i2.12

\title{
Provisions for Climate Change Technological Capability in the Agricultural Policies, Acts and Initiatives in Nigeria
}

\author{
Obiora, C. J. ${ }^{1}$ and Madukwe, M. $\mathbf{C}^{1}$. \\ ${ }^{1}$ Department of Agricultural Extension, \\ University of Nigeria, Nsukka. \\ e-mail: chyjoy_obiora@yahoo.com. 07035386888
}

\begin{abstract}
Technological capabilities are the skills (technical, managerial or organisational) that enable farm or actors to efficiently use equipment and information and improve technology. The paper reviewed the climate change technological capability provisions in agricultural policies, acts and initiatives in Nigeria. The technological capabilities examined were production, investment, minor change, linkage and strategic marketing, major change and learning capabilities. Climate Change Policy for Nigeria is still in the draft stage. Agricultural polices reviewed except the National Fadama III Project had no provision for climate change. Minor and major change capabilities were very prominent in the climate change initiatives. Acts and initiatives also showed that learning and linkage capabilities by which firms enhance their technological competence were strongly represented. Production, strategic marketing and investment capabilities however, were overtly deficient in the acts and initiatives. It recommended that the existing policies, acts and initiatives should be upgraded/reviewed to incorporate strategic marketing which fills the gap between market demands and what the firm/farm offers. Investment capabilities which showcase investment in machinery (equipment) or human resource should also be incorporated into the policies, acts and initiatives.
\end{abstract}

Key words: technological capability, climate change, climate change policy, agricultural policy, acts, initiatives

\section{Introduction}

Technological capabilities are the skills (technical, managerial or organisational) that enable firms (farm or actors) to efficiently use equipment and information and improve technology. It enables one to create new technologies and to develop new products and processes in response to a changing economic environment (Westphal, Kim and Dahlman, 1985). The development of nations depends on the 
ability of individual enterprises who are key players to develop and sustain technological capabilities and remain competitive in doing so (Industrial Development Report (IDR), 2002). The accumulation of technological capability is one of the factors that help to explain the success or failure of countries technologically and economically throughout history (IDR, 2002).

Climate change and its severe negative impacts on agriculture call for effective adaptive and mitigation strategies. For such effective adaptive and mitigation strategies, actors must have the requisite technological capabilities - the skills and information required and the learning ability to upgrade these skills when needed. Oruwari, Jev and Owei, (2002) in their work affirm that for effective climate change adaptation and mitigation, it is crucial to acquire and strengthen technological capability to produce technologies, policies and synergies needed.

In Nigeria, a lot of efforts are being put in place in a bid to effectively tackle the anticipated impacts of climate change (Adejuwon, 2011, Head, Special Climate Change Unit (SCCU), Personal communication Sept, 12, 2011). These efforts have resulted to the formulation of certain policies, acts and initiatives. Sequential to Nigeria being a signatory to United Nation Framework Convention on Climate Change (UNFCCC) under the Non-Annex I parties, it is mandated to develop some initiatives to help her curb the impact of climate change. Some of these initiatives include the production of the First National Communication (FNC), Second National Communication (SNC), Nationally Appropraite Mitigation Action (NAMA), National Adaptation Strategy and Plan of Action on Climate Change for Nigeria (NASPA-CCN) and Climate Change Adaptation Strategy Technical Reports -Nigeria (CCASTR). Since technological capability accumulation is crucial for effective climate change adaptation and mitigation, there is need therefore to address these questions -are there provisions for technological capability in the existing policies, acts and initiatives which are meant to control climate change? Which technological capabilities exist in these policies, acts and initiatives and which ones are lacking? The paper therefore aimed at:

(i) discuss approaches to the analysis of technological capability;

(ii) discuss some agricultural policies, agricultural programmes, Climate Change Policy, National Climate Change Commission Bill (NCCCBA) 2011, NASPA-CCN, and CASTRA, and identify climate change technological capability provision in each.

\section{Approaches to the analysis technological capability}

There are several approaches to the analysis of technological capability. Some of these approaches include those of Lall (1992); Bell and Pavitt (1993); Weiss Jr (1993); Ernst, Mytelka and Ganiatsos (1994) and Biggs, Manju and Srivastava (1995). Lall (1992) distinguished two forms of technological capability i.e. firm (farm) level technological capabilities (FLTC) and national level technological capabilities (NLTC). The framework of Bell and Pavitt (1993) describes the process of international technology transfer and technological accumulation in 
developing countries. Weiss Jr. (1993) framework consists of development of human and institutional resources and the eventual development of a modern integrated system that can compete effectively across a broad range of world markets. Ernst, et al. (1994) in their approach categorized capability in terms of production, investment, minor change, strategic marketing, linkage and major change. However, Biggs, et al. (1995), recognized the categorization by Ernst et al. (1994) but added another approach which is the learning capability/mechanism. In this study, the approach used by Ernst et al. (1994) and Biggs et al. (1995) was the focus.

\section{Investment capability}

Biggs, et al. (1995) defined investment capability as the skills and information needed to identify feasible investment projects, locate and purchase suitable (embodied and disembodied) technologies, design and engineer the plant, and manage the construction, commissioning and start-up. It can include subsidiary activities like procurement of equipment, training and recruitment of workforce and start-up of operations (Biggs, et al. 1995). Similarly, Aderemi, Oyebisi, and Adeniyi (2009), described it as all the skills required before the investment is undertaken and needed to carry it out. They include the capabilities to assess the feasibility and profitability of a project, to define its detailed specification, the technology required and the selection of its best sourcing, the negotiations of the purchase (cost and terms), the skills to erect the civil constructions and the equipment, to draw its detailed engineering, to recruit and train the skilled personnel required, and eventually to design the basic process and supply the equipment.

Within the agricultural innovation system, which is defined as a complex, open and dynamic human activity systems in which actors (individuals, groups, and organisations) apply their minds, energies and resources to innovation in agriculture, investment capability could include purchasing needed machineries for teaching and research with respect to climate change. It could also entail investment made in human resources in other to enhance productivity. Investment at the farm level could be in terms of additional farm inputs, increase in farm area, purchase of new crop varieties or livestock, purchase of both processing and storage facilities.

\section{Production capability}

Production capabilities include the skills necessary for the efficient operation of a plant with a given technology, and its improvement over time. Once a firm has acquired a technology of any sort, it must have adequate production capabilities to remain in business. Ernst et al. (1994) therefore defined production capabilities as the skills and knowledge needed for the operation and improvement of a plant. Production capabilities include both process technological capabilities as well as product capabilities, such as product redesign, product quality improvement and introduction of new products. In the agricultural innovation system, efficient operation of a farm with a given technology could include using a new variety of 
crops, new species of animals, adopting new plant density, new fertilizer application rate and improved harvesting techniques in adapting to climate change.

\section{Minor change capability}

Minor change capability is the firm's ability to improve and adapt continuously its products and processes. According to Oyeyinka (1997) and Akinbinu (2001), it is the ability to adapt and improve continuously, incremental upgrading of product design and process technology. It also refers to the vast area of adaptive engineering and organizational adjustments involved in the incremental upgrading of product design and performance features and of process technology (Namusonge, 2004).

Farmers are known to change the recommendation on agro-technology to suit their local conditions. Minor changes could include changes made by the farmer as he changes his planting time and other farming practises to help him cope with the challenges of climate change. Without strong minor change capabilities, a farm is ill-equipped to reap the dynamic benefits of technology diffusion.

\section{Major change capability}

Major change capability is defined as the knowledge and skills required for the creation of new technology, i.e. major changes and core features of products and production processes (Ernst, et al. 1994). Major change capabilities are derived from many sources including in-house research and development. Knowledge that underlies major change capability can in principle be externally sourced from universities and from public and private research laboratories. Major changes in the education sub- system will include changes in the teaching and learning curricula which could be made by the education sub-system. At the farm-level, a major change could include the adoption and use of agrochemicals among farmers who had not been using it, mixed farming and crop diversification.

\section{Strategic marketing capability}

In a growing number of industries/firms, competitive success requires strong product differentiation capabilities whose development depends on whether producers can build up close links with customers and identify in time their needs and changing demands. Thus marketing should be a part of firm technological capabilities. Strategic marketing capability is the knowledge and skills for collecting market intelligence, for development of new markets and for establishing distribution channels and customer services in order to be able to translate its knowledge about customer requirements into successful products and services (Ernst et al. 1994). Rather than exploiting given markets, strategic marketing aims primarily at the development of new market. Its main purpose is to bridge the gap between market demands and what the firm/farm offers. In the agricultural innovation system, strategic marketing could entail efforts of the research and extension sub- systems in having close links with their clients which will help them 
understand the need and changing demand of their clients with regards to climate change.

\section{Linkage capability}

Technological capabilities are rarely acquire in isolation. Linkage capability involves close cooperation between organisations (Lall, Barba-Naverette, Teitel and Wignaraya, 1994; Mytelka and Farinelli, 2000). Linkage capability is therefore defined as the skills needed to swap information, technology and skills between establishments (suppliers, consultants and technology institutions) (Dominguez and Brown, 2004).

When attempting to adapt and absorb new agricultural technologies, farmers interact and exchange technical inputs with other farmers. Within agricultural innovation system, linkage capabilities refer to the capacity to manage interactions and information-sharing among different divisions such as research and technology transfer sub systems. With relevance to the agricultural innovation system, the capacity to manage interactions and information-sharing (i.e. linkage capability) could be within firm e.g. linkages between researchers in a given research institution, linkages farmers have among themselves etc and from one firm to another e.g. the linkage between farmer and technology transfer subsystems, linkage between education and farmer sub-systems, linkage between technology transfer and the education sub-system, linkage between government and education sub-system etc.

\section{Learning capability}

According to Figueiredo (2003), learning capability is a process that permits the company (firm/farm) to accumulate technological capability. Similarly, Figueiredo (2007) defined it as the various processes that permit firms, companies, industrial sectors and countries to accumulate their own capabilities to carry out productionrelated and diverse types and levels of innovative technological activities over time. Learning is essentially considered as a knowledge accumulation process (Doranova, Costa and Duysters (2009). Gupta and Govindarajan (2000) disaggregate this process into knowledge creation, acquisition, and retention while Davenport and Prusak (2000) suggested that learning consists of transmission, absorption and culminating in a behavioural change by the recipient. Many authors recognize the lack of absorptive capacity in the recipient as a friction which slows or prevents learning (Whangthomkum, Igel and Speece, 2006; Lin, Tan and Change 2002; Davenport and Prusak, 2000; Wong, Shaw and Sher, 1999; Kim, 1997). Cohen and Levinthal (1990) in their seminal work highlighted the fact that organizations cannot benefit from external knowledge flows just by being exposed to them; instead, they must develop absorptive capacity which authors define as the ability to recognize the value of new external knowledge and then assimilate and utilise such knowledge for commercial ends or beneficial end. Biggs, et al. (1995) distinguished two types of learning capability- private and collective. Private learning capability may be internal to the firm, such as in-house training and 
research and development $(R \& D)$ or external, involving relationships with buyers and suppliers, interactions with other firms through subcontracting, industry networks and hiring local or foreign consultants. Collective mechanisms, on the other hand, consist of technical support services provided by NGOs, business associations, government or donors.

In the agricultural innovation system, for climate change actors to be effective in addressing the challenges of climate change, they first have to acquire knowledge to build up and accumulate their own technological capabilities. In other words, they need to engage in a process of 'learning'. Learning at the farm level emerge and accumulate through a continuous process of trial and error, testing of different 'crop-growing techniques', on the basis of an experimental and pragmatic approach to the solutions of problems. This articulated process is referred to as infarm learning (Andreoni, 2011). Thus, farmers, extension agents and others can learn from field experience.

\section{Some Agricultural Policies and Programmes, Climate Change Policy, Acts and Initiatives and Technological Capability Provisions}

\section{Agricultural policies and programmes}

Agricultural policies are statements of the general guidelines, plans, and strategies to guide the actions of government and other relevant agencies in the agricultural sector (Adebayo, Babu, and Rhoe, (2009). In Nigeria, a lot of agricultural policies and programmes have been put in place. Some of these policies include Agricultural Commodity Marketing and Pricing Policy, Input Supply and Distribution Policy, Agricultural Input Subsidy Policy, Agricultural Mechanization Policy, Nigeria Agricultural Policy while some of the programmes include River Basin Development Authority, Agricultural Development Authority and National Fadama.

\section{Agricultural Commodity Marketing and Pricing Policy}

The major instrument of Agricultural Commodity Marketing and Pricing Policy was the establishment of six national commodity boards in 1977 to replace the regional, multi-commodity boards that operated in 1954 (Manyong, Ikpi, Olayemi, Yusuf et. al (2005). The six new national commodity boards were for cocoa, groundnut, palm produce, cotton, rubber, and food grains. The case of the grains marketing board was particularly unique as it represented the first effort ever made to extend the marketing board system to cover food crops. The National Grains Board handled maize, millet, sorghum, wheat, rice, and cowpea. It administered a guaranteed minimum price policy whereby floor prices were nationally set for each of the six grain crops and the board would intervene as a buyer of last resort if and when their regular market prices fell below the guaranteed minimum. The board also operated a strategic grain reserve scheme. Thorough analysis of this policy showed that climate change related issues were not accommodated in it. There was no mention on how climate change can affect the marketing and pricing of agricultural products. 


\section{Agricultural Mechanization Policy}

The need for a coherent agricultural mechanization policy became very pressing in the early 1970s in view of an increasing shortage of agricultural labour that necessitated the substitution of some appropriate forms of mechanical power for human labour. In an attempt to achieve the objectives of an agricultural mechanization policy, the following policy instruments were adopted:

- the operation of tractor hire units by states

- liberalized import policy in respect of tractors and agricultural equipment

- massive assistance program to farmers on land clearing through cost subsidies

- the launching of a machinery ownership scheme in 1980 under which the Federal Government provided half of the purchase cost of farm machinery to be owned and used by farming cooperatives or group farms.

This Policy showed no concern on how climate change will affect it or how the handling of these machines could aggravate climate change.

\section{Agricultural Extension and Technology Transfer Policy}

The most important feature of agricultural extension policy in the 1970s was the demise of the old system of state-based general agricultural extension services. Under this old system, only states employed and utilized the services of agricultural extension personnel and mainly for general advisory services to farmers. The agricultural extension and technology transfer policy objective was to promote the adoption of new agricultural technologies by farmers through a nationally coordinated extension service system. The basic strategy involved the use of a unified agricultural extension system under the aegis of state wide ADPs.

An important, relatively recent development in agricultural research and extension in the country involved the creation of institutional arrangements for a strong linkage between agricultural research, extension, and farmers. In 1987, the National Agricultural Extension and Research Liaison Services evolved through a long process of mutation to become the organ for the planning and coordination of agricultural extension liaison nationwide and for conducting research on technology transfer and adoption. There was no provision for climate change as it relates to extension workers and their clients in this policy.

\section{Nigerian Agricultural Policy}

The 2001 Nigerian Agricultural Policy was launched in 2001 to replace the one of 1988. It seeks to attain self-sustaining growth in all sub-sectors of agriculture, a structural transformation of the overall socio-economic development of the country and the improvement of livelihoods. Its strategies also aim at achieving selfsufficiency and improvement of technical and economic efficiency in food production through the introduction and adoption of improved technologies of 
production, efficient utilization of resources and the enhancement of producer capacities. The overall objectives of the New Nigerian Agricultural Policy (2001) are summarized thus:

(i) attainment of self-sufficiency in basic food commodities with particular reference to those which consume considerable shares of Nigeria's foreign exchange and for which the country has comparative advantage in local production

(ii) increase in production of agricultural raw materials to meet the growth of an expanding industrial sector

(iii) increase in production and processing of exportable commodities with a view to increasing their foreign exchange earning capacity and further diversifying the country's export base and sources of foreign exchange earnings

(iv) modernization of agricultural production, processing, storage and distribution through the infusion of improved technologies and management so that agriculture can be more responsive to the demands of other sectors of the Nigerian economy

(v) creation of more agricultural and rural employment opportunities to increase the income of farmers and rural dwellers and to productively absorb an increasing labour force in the nation.

Unfortunately, however, this policy did not address issues related to the impacts of climate change on agriculture. It only focused on how to achieve increase food production.

\section{National Fadama}

The phase 1 of the project launched in 1988 and financed by the World Bank at the cost of $\$ 45$ million was implemented in the northern states and provided support for dry season farming through the supply of small scale irrigation implements and construction of dams for crops and livestock farming. The second phase started in 2004 covering 12 states and incorporating poverty alleviation and farmer income generation strategies as targets. It seeks to address factors in production glut in some parts of the country (even at times that food prices continued to rise in all parts) and sought to raise the capacity of producers through production infrastructure, inputs and advisory services. The Phase 3 of the programme on going in many states of the Federation. The Fadama Project had some considerations on the environment. It does this by establishing methodologies for environmental and social impact assessment procedure within the community-driven development (CDD) subproject cycle (World Bank, 2008). It will also assess the potential environmental impact of the project whether positive or negative and propose mitigation measures which will effectively address these impacts. This shows that Fadama III Project has consideration for climate change issues. The overt technological capability exhibited in the Project is investment 
capability. The Fadama III has six components and there is a representation of how investment would be made in each component (World Bank, 2008). This provides for strong investment capability.

\section{River Basin Development Authorities (RBDAs)}

The River basin development was promulgated in 1976 for the purpose of harnessing water resources for farmers throughout the country. As noted by Offodile (2000), the River Basin Authorities were expected to carry out the following functions:- i) undertake comprehensive development of ground water resources for multipurpose use ii) undertake Watershed Management Schemes for flood and erosion control iii) construct and maintain dams, dykes, wells or boreholes, irrigation and drainage systems iv) provide water from reservoirs, wells and boreholes for urban and rural water supply schemes v) resettle persons affected by the works and schemes specified in (iii) and (iv) above.

Given the adverse impact of climate change on water resources, it was a very big error that this Programme had no provisions for climate change and climate change related issues.

\section{Climate Change Policy}

Building Nigeria Resilience to Climate Change (BNRCC) noted that when the phenomenon of Climate Change caught the World's attention, Nigeria was one of the 154 countries that initiated the Convention in Rio in 1992, and she became a party as soon as the Convention came into force. Nigeria was also a party to the ratified Convention on the $29^{\text {th }}$ of August, 1994 and has ratified the Kyoto Protocol. As a signatory to United Nation Framework Convention on Climate Change (UNFCCC) under the Non-Annex I parties, Nigeria's obligation includes the following:

- To produce four key National Communications

- To produce four in-depth review summaries

- To produce the National Adaptation Programme of Action

- To produce a Global Climate Observing System (GCOS) Report

As a party to the Convention, Nigeria must meet the obligations and commitments to the Convention, which is aimed primarily at controlling climate change by reducing to the absolute minimum the concentration of greenhouse gases in the atmosphere. In a bid to meet up with these demands of the Convention, the Special Climate Change Unit (SCCU) within the Federal Ministry of Environment was launched in 2006. This Unit was upgraded to the status of a department in late 2011(Adejuwon, J. 2012. Head, SCCD, Personal communication Feb. 22, 2012). 
Sustainable climate change policies are prerequisites for a strong national adaptive capacity (Oladipo, 2010); consequently, Special Climate Change Department (SCCD) recognizes the need to address climatic change in a policy responsive and strategic way (Adejuwom, 2011. Personal communication Sept, 12, 2011). It has, therefore, put in place a draft Climate Change Policy and Response Strategy with the strategic goal of fostering a low-carbon, high growth economic development path and building a climate resilient society. The draft Policy includes objectives related to climate change mitigation, adaptation, climate science and technology, public awareness, private sector participation, and strengthening national institutions and mechanisms (Okibe, R. Scientic, SCCD. Personal communication Sept, 12, 2011)). It is multi-disciplinary in nature as it articulated roles and programmes for the various sectors of the economy. The draft policy would enable Nigeria generate energy from renewable clean sources, reduce green house gases, enhance private sector participation in climate change issues and above all reduce Nigeria's vulnerability to the impact of climate change. Okibe (2011) and Adejuwom (2011) maintained that the draft policy is not yet made public as it will be presented to Federal Executive Council (FEC) in 2012.

\section{Acts}

\section{National Climate Change Commission Bill (NCCCBA) (2011)}

The National Assembly of the Federal Republic of Nigeria in 2011 passed a bill to create a National Climate Change Commission (National Climate Change Commission Bill, 2011). The Commission shall have the President of the Federal Republic as Chairman. The members of the commission will be ministers charged with energy, science and technology, environment, housing and urban development, water resources, agriculture and rural development, justice, foreign affairs, finance and health. Other members of the Commission shall be professionals from the following ministries and agencies e.g Nigerian Institute of Geological and Mining Research, Nigerian Institute of Oceanography, Nigeria Metrological Agency (NIMET), Nigeria Communication Commission, Nigerian Electricity Regulatory Commission (NERC), Nigerian Atomic Energy Commission, Nigerian Academy of Science, Representative of Civil Society/Non-Governmental Organization. Seventy (70) percent of monies in the accounts of the Ecological Fund relating to the states affected by climate change.

The most conspicuous technological capability provision in the Bill was the learning and linkage capabilities. This is because the proposed membership of the Commission will be made up of actors from varied ministries and units; this is expected to result in interactive learning processes and linkage. Such interactive learning and linkage will help to tackle climate change in a multidimensional and multi-institutional approach. However, strategy for evaluating and applying lessons learned was absent in the Bill. Investment capability was however vaguely provided in the Bill. This is because it did not focus strategy to link resources, both 
financial and intellectual to critical needs. Strategic marketing, production, minor and major change capabilities were not provided for in the Bill

\section{Initiatives}

\section{First National Commission (2003)}

Nigeria's major achievement in responding to the UNFCCC and the Protocol is the production of the First National Communication (FNC) in November, 2003 (http:/www.nigeriaclimatechange.org). The FNC (2003) summarized the inventory of Green House Gases (GHGs) emitted from Nigeria and the impacts of climate change in Nigeria. It also assessed the vulnerability of Nigeria to climate change and offered mitigation and adaptation measures. The inventory of GHG(s) as recorded by the FNC (2003) from agriculture as follows: emissions from a combined livestock population of 509,000 in 1994 led to the emissions of $1115 \mathrm{Gg}$ $\mathrm{CH} 4$. Similarly, rice production led to the emissions of $1090 \mathrm{Gg} \mathrm{CH} 4$, while savannah burning generated $109 \mathrm{Gg} \mathrm{CH} 4,3.4 \mathrm{Gg} \mathrm{N} 2 \mathrm{O}, 2870 \mathrm{Gg}$ CO and $120 \mathrm{Gg}$ NOX. The field burning of $61.2 \mathrm{Mt}$ of agricultural crop wastes also led to the emissions of $34 \mathrm{Gg}$ of $\mathrm{CH} 4,0.7 \mathrm{Gg} \mathrm{N20}, 720 \mathrm{Gg} \mathrm{CO}$ and $26 \mathrm{Gg}$ of NOX. Thus, the sector emitted $2.3 \mathrm{Tg} \mathrm{CH} 4$ and $3.6 \mathrm{Tg} \mathrm{CO}$ into the atmosphere, while $\mathrm{N} 2 \mathrm{O}$ and NOX emissions were 4.1 and $148 \mathrm{Gg}$, respectively (Federal Ministry of Environment (FME), 2003).

It also assessed the impacts of climate change on agriculture and the many possible adaptation options in agriculture for responding to climate change. They include among others: creation, diversification and study of local vegetation resources in order to find new plant species and varieties that would have higher resistance to anticipated temperature increase and reduced rainfall; improving local agricultural crop varieties that are well acclimated and drought and pest resistant and linking crop production to meteorological forecast.

The First National Commission (2003) which is the first response of Nigeria to climate change lacked all the capabilities except minor and major capabilities which it reiterated to include finding new crop varieties that will tolerate adverse climate among others. It was mainly a documentary on the inventory of GHG(s) emissions in Nigeria. The Second National Commission is still on-going.

\section{Climate Change Adaptation Strategy Technical Reports - Nigeria (CCASTR)}

In line with the demands of the UNFCCC for Non-Annex I parties to produce a National Adaptation Programme of Action, the SCCD of the Federal Ministry of Environment in collaboration with the Building Nigeria's Response to Climate Change (BNRCC) produced a technical volume, entitled Climate Change Adaptation Strategy Technical Report (CCASTR) in October, 2011(NEST and Tegler, B. (eds.) 2011). The Climate Change Adaptation Strategy Technical Report (CCASTR) is a collaborative effort providing a broad perspective of recommendations on climate change hazards, impacts, vulnerability, adaptation options and policy for five sectors and 18 sub-sectors. The CCASTR examined 
climate change adaptation in the following five sectors: Infrastructure Sector (subsectors of Energy, Transport, Communications and Housing, Industry and Commerce), Agriculture Sector (sub-sectors of Crops and Livestock), Natural Resource Sector (sub-sectors of Coastal Resources, Water Resources, Fishery Resources, Forestry Resources, Biodiversity), Health and Sanitation Sector (subsectors of Human Health, Domestic and Industrial Sanitation and Waste) and Cross-Sectoral Issues (sub-sectors of Finance, Disaster Management, Migration and Security, Urban and Rural Settlements and Livelihoods, Vulnerable Groups, and Education).

The Report for each sector included an analysis of current and future trends in regard to climate change hazards, impacts, and vulnerability and provided a range of adaptation options. Based on the analysis, recommendations were presented for policies, strategies and programs needed to support climate change adaptation in Nigeria.

The impact of climate change on agriculture, adaptation action and recommended policies by the CCASTR is summarized below:

\section{Impacts}

Increased rainfall intensity gully and sheet erosion which leads, sea level rise, rising temperature, changing rainfall patterns

\section{Recommended climate change adaptation actions}

The following is a summary of climate change adaptation actions recommended for the crop sector: Developing improved crop varieties (high yielding and early maturing varieties); Developing water, heat, salt, drought, and disease resistant crop varieties; Greater support for seed banks to ensure the proper preservation of seeds and plant; Building systems for conveying climate information to farmers. It is important to build early warning systems to disseminate projected weather patterns in a timely manner. This will help to increase farmers' adaptive capacity to climate change impacts e.g., through changing planting dates, crop varieties, irrigation strategies, etc. to adapt to changing conditions for crop production; Greater support for crop insurance: Government should increase support for Nigerian Agricultural Insurance Scheme (NAIS) and farmers should register with the scheme. This will help insure farmers against crop failure due to flood, erosion and drought; Improving agricultural extension services. Extension agents are change agents in agriculture. They have the capacity to disseminate important climate change adaptation information. Therefore it is paramount to increase the number of well trained government and NGO extension staff and provide them with the tools needed to reach farmers with training programs. 


\section{The following adaptation actions were recommended for the livestock sub-sector:}

Intensive livestock keeping: Keeping livestock in a confinement instead of free range (extensive) will help farmers adapt to climate change impacts like disease infestation. Government, private sector, and NGOs can help livestock farmers adapt to climate change by providing soft loans needed to initiate intensive livestock production.

Planting trees near livestock houses and on pasture land: This strategy will help farmers adapt to severe windstorms which are responsible for destruction of livestock houses and forage land.

The CCASTR provided mainly for minor and change capabilities where it presented some changes that will be effected which included developing improved crop varieties (high yielding and early maturing varieties), developing water, heat, salt, drought, and disease resistant crop varieties, greater support for seed banks to ensure the proper preservation of seeds and plant, building systems for conveying climate information to farmers, greater support for crop insurance and improving agricultural extension services. Investment, production, strategic marketing, learning and linkage capabilities were conspicuously absent in the CCASTR.

\section{National Adaptation Strategy and Plan of Action on Climate Change for Nigeria (NASPA-CCN)}

To ensure a truly national response to the significant and multi-facetted impacts of climate change, Nigeria needs an aggressive and widely supported strategy and action plan. This strategy and plan must be integrated, comprehensive in scope, and inclusive of all stakeholders. This is what the NASPA-CCN provides for Nigeria. The NASPA-CCN was produced in November, 2011 and it outlines recommended strategies for each of the thirteen (13) priority sectors (agriculture, freshwater resources, coastal water resources and fisheries, forest, biodiversity, health and sanitation, human settlement and housing, transportation and communications, energy, industry and commerce, disaster, migration and security, livelihood, vulnerable groups and education) and defines a set of policies, programmes and measures based on these strategies. The NASPA-CCN set of policies, programmes and measures for the agriculture sector is presented below: the overall strategies among others include:

Review national agricultural and related policies and programmes: The Federal Government should review all national agricultural and related policies and programmes to determine modifications required in view of expected climate change. The review of these policies should ensure the effective participation of all stakeholders, including women and other vulnerable groups.

Early warning system: The Federal Government should review current policies and programmes for early warning, and based on this should develop and roll out 
a programme to improve availability and farmer access to short and long range weather forecasts.

Technology transfer: The Federal Government should facilitate and support efforts to identify and transfer technologies that can contribute to climate change adaptation in Nigerian agriculture, including technologies from international sources.

NASPA-CCN weakly provided for linkage and learning capabilities. This is because though it recommended policy reviewing with all the stakeholders and this can help build linkage and learning capabilities but it showed absence of strong links between, and support and participation of indigenous communities, state, and other local partners. There was also absence of a strategy for evaluating and applying lessons learned. It provided for both minor and major change capabilities. These minor and major changes were clearly stipulated under the 'overall strategies' above. These include diversifying livestocks/crops, increase access to drought resistant crops, adopting better soil management practices, increase planting of native vegetation cover etc.

\section{Conclusion and Recommendation}

Fruitful efforts geared towards climate change adaptation and mitigation which is represented in any policy, acts or initiatives must make provisions for technological capabilities. Technological capability portrays the skills (technical, managerial or organisational) that enable actors to efficiently use equipment and information and improve technology. The technology could be technology needed to tackle the impact of climate change (adaptation) or such needed to control the production of Green House Gases which is supposed to cause climate change (mitigation). Investment, production, strategic marketing, minor change, major change, learning and linkage technological capabilities provisions in some agricultural policies and programmes, acts and initiatives were reviewed. Minor change, major change, investment, learning and linkage capabilities were present in the some of the reviewed policies, acts and initiative and absent in some. Strategic marketing capability was however absent in all the policies, acts and initiative reviewed. The paper therefore concludes that the existing policies, acts and initiatives should be upgraded/reviewed to incorporate strategic marketing which fills the gap between market demands and what the firm/farm offers, furthermore, investment capabilities which showcase investment in machinery (equipment) or human resource should also be incorporated into the policy, acts and initiatives. 


\section{References}

Adebayo, K ; Babu, S and Rhoe, V (2009). Institutional capacity for designing and implementing Agricultural and Rural Development Policies and Strategies in Nigeria. Background Paper No. NSSP 008. Nigeria Strategy Support Program of the International Food Policy Research Institute (IFPRI).

Aderemi, H. O.; Oyebisi, T. O and Adeniyi, A. A. (2009). Development of a measure for technological capability in the information and communications technology industry in Nigeria. Ph. D. Student Paper Competition submitted to Globelics, Dakar, Senegal.

Akinbinu, A. (2001). Technological learning in the Nigerian Passenger Car Industry: An assessment. Nigerian Institute of Social and Economic Research (NISER) Ibadan Monograph Series No.12.

Andreoni, A. (2011). Manufacturing agrarian change. Inter-sectoral learning, agricultural production and technological capabilities. Paper to be presented at the DRUID 2011 on Innovation, strategy, and structure - organizations, institutions, systems and regions. At Copenhagen Business School, Denmark, June 15-17.

Bell, M and Pavitt, K. (1993). Technological accumulation and industrial growth: contrast between developed and developing countries. Industrial and Corporate Change. 2:157-210.

Biggs, T.; Manju S and Srivastava P. (1995). Technological capabilities and learning in African enterprises. World Bank Technical Paper 288.

Davenport, T. H. and Prusak, L. (2000). Working Knowledge: How Organizations Manage What They Know. Harvard Business School Press, Boston.

Domínguez, L and Brown, F. (2004). Measuring technological capabilities in Mexican industry. CE P A L Re vi e w. 8 3:129-144.

Doranova, A.; Costa, L and Duysters, G. (2009). Absorptive capacity in technological learning in clean development mechanism projects. UNUMERIT Working Papers. No 2011-010.

Ernst, D; Mytelka, L and Ganiatsos, T (1994). Technological capabilities in the context of export-led growth: a conceptual framework. In: D. Ernst, T. Ganiatsos and L. Mytelka (Eds.) Technological Capabilities and Export Success in Asia. 5-35. Routlegde.

Figueiredo, P. N. (2007). Technological learning and innovation in developing countries. Available at www.inderscience.com/www.newsletter/2007/article_autumn2007.pdf

Figueiredo, P.N. (2003). Learning capability accumulation and firms differences: evidence from latecomer steel. Industrial and Corporate Change. Oxford University Press. 123: 607-643. 
Gupta, A. K and Govindarajan, V. (2000). Knowledge flows within multinational corporations. Strategic Management Journal. 21:473-496.

Industrial Development Report (IDR) (2002). Innovation and learning to drive industrial development. Available at www.05idr ch5072402 industrialdev.pdf

Kim, L (1997). From Imitation to Innovation: the Dynamics of Korea's Technological Learning. Boston, MA. Harvard Business School Press.

Lall, S. (1992). Technological capabilities and industrialization. World Development. 20 (2) 165-I86. Amsterdam, Elsevier Science.

Lall, S.; Barba-Naverette, G.; Teitel, S and Wignaraya, G (1994). Technology and Enterprise Development. Ghana Under Structural Adjustment. London, Macmillian.

Lin, C.; Tan, B and Change, S. (2002). The critical factors for absorptive capacity. Industrial Management and Data Systems. 102 (6): 300-308.

Manyong, V. M., Ikpi, A., Olayemi, J. K., Yusuf, S.A., Omonona, B.T., Okoruwa, V and Idachaba, F. S. (2005). Agriculture in Nigeria: identifying opportunities for increased commercialization and investment. IITA, Ibadan, Nigeria. 159.

Mytelka, L and Farinelli, F (2000). Local clusters, innovation systems and sustained competitiveness, Mastricht: UNUINTECH (mimeo).

Namusonge, G. S (2004). The Role of Development Financial Institutions in the Aquisition of Technological Capabilities by Small and Medium Enterprises in Kenya. ATPS Working Paper Series No. 41.

National Climate change commission Bill (2011). No. 539

NEST and Tegler, B. (eds.) (2011). Climate Change Adaptation Strategy Technical Reports- Nigeria, (CCASTR). Building Nigeria's Response to Climate Change. Ibadan, Nigeria: Nigerian Environmental Study/Action Team (NEST).)

Offodile, M.E (2000). The development and management of ground water for water supply in Nigeria. Presented at the 2nd Fellow's Workshop of Nigerian Mining and Geo-science Society (NMGS).

Oladipo, E. (2010). Towards enhancing the adaptive capacity of Nigeria: a review of the country's state of preparedness for climate change adaptatation. Report submitted to Heinrich Boll Foundation Nigeria.

Oyeyinka, B. (1997). Technological learning in African Industry: a study of engineering firms in Nigeria. Science and Public Policy. 24 (5): 309-318.

Weiss Jr (1993). Scientific and technological responses to structural adjustment. Technological and Society. 15:281-299. 
Westphal, L. E., Kim, L. and Dahlman, C. J. (1985). Reflections on the Republic of Korea's acquisition of technological capability. In: N. Roseberg, and C. Frischtak (eds.) International Technology Transfer: Concepts, Measures and Comparison. New York, Praeger :167-221.

Whangthomkum, N.; Igel, B and Speece, M. (2006). An empirical study of the relationship between absorptive capacity and technology transfer effectiveness. International Journal of Technology Transfer and Commercialisation. 5 (1-2): 31-55.

Wong, V.; Shaw, V. and Sher, P. (1999). Intra-firm learning in the technology transfer a study of Taiwanese information technology firms. International Journal of Innovation Management. 3 (4): 427-458.

World Bank (2008). Project Appraisal Document on a Proposed Credit in the amount of SDR 153.4 Million to the Federal Republic of Nigeria for a Third National FADAMA Development (Fadama III) Project. 